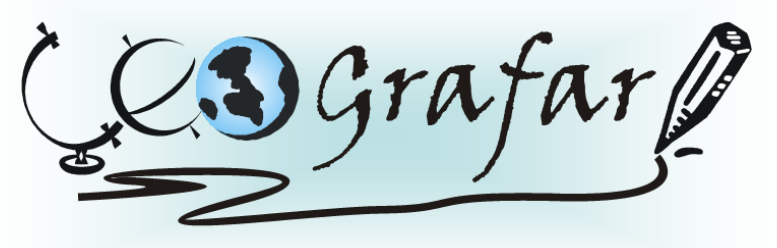

Revista Eletrônica do Programa de Pós-Graduação em Geografia - UFPR

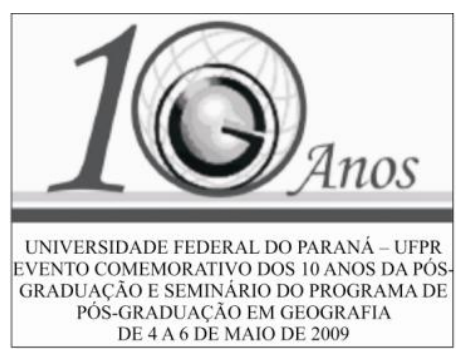

\title{
ESPACIALIDADES FEMININAS NAS COMUNIDADES RELIGIOSAS BAHÁ'Í E ISLÂMICA: UM ESTUDO DAS REPRESENTAÇÕES SIMBÓLICAS
}

\author{
EMERLI SCHLÖGL ${ }^{1}$ \\ SYLVIO FAUSTO GIL FILHO ${ }^{2}$
}

\section{LINHA DE PESQUISA: TERRITÓRIO, CULTURA E REPRESENTAÇÃO}

Evidenciam-se nas culturas religiosas aspectos simbólicos do sagrado feminino e do sagrado masculino, as religiões muitas vezes pendem mais para um lado do que para o outro e em certas circunstâncias apontam para o equilíbrio entre estas duas forças potenciais. Neste cenário o papel desempenhado por mulheres e homens no interior das tradições religiosas é bem variado, apontando para igualdades ou desigualdades.

Neste contexto, estudar e analisar as espacialidades femininas nas comunidades religiosas bahá'í e islâmica, por meio da hermenêutica de suas representações simbólicas, oferece a oportunidade de compreender estas dinâmicas, bem como perceber quais são as delimitações espaciais que as mulheres ocupam nestes dois cenários, bem diversos.

Estas duas vertentes religiosas apresentam espacialidades femininas muito distintas. As duas religiões surgem no contexto da geografia e história do oriente médio, porém as compreensões das implicações de gênero em seu contexto simbólico são bastante particulares e diferenciadas em cada uma delas.

Os jogos de poder evidenciados na dominação do masculino sobre o feminino definiram a organização de muitas religiões. Os direitos e deveres femininos e masculino, na estruturação da legislação dos estados, historicamente passaram pela influência dos códigos simbólicos das tradições religiosas. As leis que determinaram os comportamentos sociais, muitas vezes, se originaram dos símbolos expressos em mitologias religiosas complexas e determinantes.

Palavras chave: espacialidades, representações, religiões.

\footnotetext{
1 emerlischlogl@hotmail.com

${ }^{2}$ Professor orientador
} 